\title{
Rheumatoid factor and anti-cyclic citrullinated peptide (anti-CCP) antibodies with hepatitis B and hepatitis C infection: Review
}

\author{
Orhan Zengin ${ }^{1, A-D}$, Hamit Yıldız 2, D, Zeynep Hanım Demir ${ }^{3, D}$, Muhammed Sait Dağ ${ }^{4, D}$, \\ Musa Aydınlı ${ }^{4, D}$, Ahmet Mesut Onat ${ }^{5, D}$, Bünyamin Kisacık ${ }^{5, A, D}$ \\ ${ }^{1}$ Faculty of Medicine, Gaziantep University, Turkey \\ ${ }^{2}$ Department of Internal Medicine, School of Medicine, Gaziantep University, Turkey \\ ${ }^{3}$ NYU School of Medicine, Center for Cognitive Neurology, New York, the USA \\ ${ }^{4}$ Department of Gastroenterology, School of Medicine, Gaziantep University, Turkey \\ ${ }^{5}$ Department of Rheumatology, School of Medicine, Gaziantep University, Turkey \\ A - research concept and design; $\mathrm{B}$ - collection and/or assembly of data; $\mathrm{C}$ - data analysis and interpretation; \\ $D$ - writing the article; $E$ - critical revision of the article; $F$ - final approval of article
}

\section{Address for correspondence \\ Orhan Zengin}

E-mail: drorhanzengin@gmail.com

Funding sources

None declared

Conflict of interest

None declared

Received on 0ctober 17, 2015

Revised on January 17, 2016

Accepted on May 10,2016

\begin{abstract}
Background. Viruses are common and are involved in the etiology of idiopathic rheumatological diseases. Hepatitis B virus (HBV), a member of the family Hepadnaviridae and hepatitis ( virus (HCV), play an important role in the undetermined etiology of arthritis. The clinical manifestations of hepatitis $B$ and $($ show similarities with various diseases, such as rheumatic diseases. Anti-cyclic citrullinated peptide (anti-CCP) is a specific serological marker for rheumatoid arthritis.

Objectives. The aim of this study was to analyze anti-CCP and rheumatoid factor (RF) levels in patients with a hepatitis $B$ and $C$ infection.
\end{abstract}

Material and methods. Forty-four patients with hepatitis B, 43 patients with hepatitis C, 25 patients with rheumatoid arthritis, and 46 healthy control serums and their RF and anti-CCP levels were compared. RF was measured by the nephelometer, which detects IgM-RF. Anti-CCP was measured using enzymelinked immunosorbent assay (ELISA) that is included in the second-generation anti-CCP antibody assays (anti-CCP2).

Results. The anti-CCP positivity levels were 20.5\%, 32.5\%, 72.4\% and 10.9\% for HBV, HCV and RA groups and healthy control group, respectively. When the groups were compared based on their RF positivity and anti-CCP positivity while the values for HBV and $\mathrm{HCV}$ group and healthy control group were the same, in RA group there is a significant difference to the rest of the groups $(p<0.01)$.

Conclusions. Anti-CCP may be positive for HBV and HCV as well, but it is a sensitive and specific immunological marker for RA diagnosis, especially in high-titres.

Key words: rheumatoid arthritis (RA), hepatitis, anti-CCP

DOI

10.17219/acem/63095

Copyright

Copyright by Author(s)

This is an article distributed under the terms of the

Creative Commons Attribution Non-Commercial License

(http://creativecommons.org/licenses/by-nc-nd/4.0/) 
Anti-citrullinated protein antibodies (ACPA) and RF are autoantibodies present in the majority of rheumatoid arthritis patients. Among these, anti-cyclic citrullinated peptide (anti-CCP) antibodies are widely known to be an important diagnostic and prognostic tool due to their high specificity. It has been determined that antiCCP has a sensitivity level between $69.6 \%$ and $77.5 \%$ and a specificity between $87.8 \%$ and $96.4 \%$ in RA diagnosis. ${ }^{4}$ anti-CCP and RF are important indicators in RA diagnosis, but they can also be positive for various infections and connective tissue diseases. ${ }^{5-9}$ Anti-CCP and rheumatoid factor (RF) may be traced in some viral infections just as in hepatitis B (HBV) and hepatitis $\mathrm{C}(\mathrm{HCV})$ infections respectively. ${ }^{14}$

The diagnosis of chronic HBV and HCV infections is based on the HBsAg and anti-HCV positivity persisting for more than 6 months. ${ }^{2}$ Certain characteristics of chronic $\mathrm{HBV}$ and $\mathrm{HCV}$ infections are similar to those of rheumatic and renal diseases. Any of the symptoms of chronic HBV and HCV infections such as arthralgia, peripheral arthritis or laboratory findings like elevated acute phase reactants including C-reactive protein (CRP), erythrocyte sedimentation rate (ESR) and positivity of RF are important markers for the diagnosis of inflammatory rheumatic diseases. ${ }^{3}$ The aim of this study was to evaluate the rate of anti-CCP and RF positivity in hepatitis $B$ and $C$ infection.

\section{Material and methods}

The study subjects consisted of 44 patients with hepatitis B (male/female: 18/26), 43 patients with hepatitis C (male/female: 10/33), 25 patients with rheumatoid arthri-

Table 1. Demographic features of all study groups

\begin{tabular}{|l|c|c|c|c|c|}
\hline \multicolumn{1}{|c|}{ Patients } & $\begin{array}{c}\text { Chronic } \\
\text { hepatitis B } \\
\mathrm{n}=44\end{array}$ & $\begin{array}{c}\text { Chronic } \\
\text { hepatitis C } \\
\mathrm{n}=43\end{array}$ & $\begin{array}{c}\text { Rheumatoid } \\
\text { arthritis } \\
\mathrm{n}=25\end{array}$ & $\begin{array}{c}\text { Healthy } \\
\text { control } \\
\mathrm{n}=46\end{array}$ & p-value \\
\hline Age (years) & $34.2 \pm 7.4$ & $34.3 \pm 6.0$ & $38.4 \pm 7.8$ & $33.9 \pm 7.2$ & 0.079 \\
\hline Sex (male/female) & $18 / 26$ & $10 / 33$ & $9 / 16$ & $18 / 28$ & 0.068 \\
\hline
\end{tabular}

Table 2. Laboratory findings of study population

\begin{tabular}{|l|c|c|c|c|}
\hline \multicolumn{1}{|c|}{ Study groups } & Levels of RF & RF positivity & $\begin{array}{c}\text { Levels of anti- } \\
\text { CCP }\end{array}$ & $\begin{array}{c}\text { Anti-CCP } \\
\text { positivity }\end{array}$ \\
\hline Hepatitis B & $14.5 \pm 11.0$ & $5(11.4 \%)$ & $22.1 \pm 23.7$ & $9(20.5 \%)$ \\
\hline Hepatitis C & $16.0 \pm 11.0$ & $7(16.3 \%)$ & $28.7 \pm 24.3$ & $14(32.5 \%)$ \\
\hline $\begin{array}{l}\text { Rheumatoid } \\
\text { arthritis }\end{array}$ & $60.4 \pm 82.5$ & $15(60 \%)$ & $141.1 \pm 137.4$ & $18(72.4 \%)$ \\
\hline \begin{tabular}{l} 
Healthy control \\
\hline P-value
\end{tabular} & $7.8 \pm 4.1$ & $1(2.2 \%)$ & $18.7 \pm 4.4$ & $5(10.9 \%)$ \\
\hline
\end{tabular}

RF - rheumatoid factor; anti-CCP - anticyclic citrullinated peptid. tis (male/female: 9/16) and 46 healthy individuals as the control group (male/female: 18/28). All patients with RA fulfilled the 1987 ACR criteria for RA. ${ }^{10}$ The diagnosis of chronic HBV infection is based on the persistence of the hepatitis B surface antigen (HBsAg) for more than 6 months and patients were determined to be carriers of inactive HBV (level of HBV DNA below $2000 \mathrm{IU} / \mathrm{mL}$ and serum levels of ALT that remained normal). Chronic hepatitis $\mathrm{C}$ infection is defined by the presence of anti-HCV and HCV-RNA positivity for at least 6 months. Serum levels of ALT remained normal in all patients with $\mathrm{HCV}$ group. No patient received antiviral therapy in both HBV and HCV groups. No specific musculoskeletal symptoms and findings in all patients carrying chronic phase hepatitis B and chronic hepatitis $C$ have been defined yet. Serum samples were obtained from venous blood, frozen and stored at $-80^{\circ}$ for future analysis. Anti-CCP and RF were studied on these samples. RF was measured by the Nephelometer, which detects IgM-RF and the normal range was between 0 and $20 \mathrm{IU} / \mathrm{mL}$. Anti-CCP was measured using enzyme-linked immunosorbent (ELISA), which is included in the second generation anti-CCP antibody assays (anti-CCP2) and manufacturer's cut-off for positivity was $\leq 25 \mathrm{U} / \mathrm{mL}$. Anti-CCP levels were classified in titre as low, moderate and high for values $25-50 \mathrm{U} / \mathrm{mL}$, $50-75 \mathrm{U} / \mathrm{mL}$ and $75 \mathrm{U} / \mathrm{mL}$ respectively. All participants were informed on the study, and the procedures complied with the Declaration of Helsinki and institutional guidelines. The Ethics Committee of Gaziantep University approved the study, and informed consent was obtained from all patients.

As for the statistical analysis, the Statistical Package for Social Sciences (SPSS) was used to analyze the data. A one-way ANOVA test was used for multiple comparisons. In addition, the $\chi^{2}$ and Fisher's exact tests were used for categorical variables, and the Tukey test was used to compare mean values. $\mathrm{P}$ values $<0.05$ were considered as statistically significant.

\section{Results}

The average ages in the study groups for chronic hepatitis B, chronic hepatitis $C$, RA groups and healthy control group were $34.2 \pm 7.4$, $34.3 \pm 6.0,38.4 \pm 7.8$ and $33.9 \pm 7.2$ respectively. There were no meaningful differences of age or gender in the groups $(\mathrm{p}=0.079, \mathrm{p}=0.068$ respectively). Demographic characteristics of the patients and healthy controls are presented in Table 1. 
Table 3. Comparisons of anti-CCP positivity levels of groups

\begin{tabular}{|l|c|c|c|c|c|}
\hline \multicolumn{1}{|c|}{$\begin{array}{c}\text { Anti-CCP } \\
\text { positivity }\end{array}$} & $\begin{array}{c}\text { Hepatitis B } \\
(\%)\end{array}$ & $\begin{array}{c}\text { Hepatitis C } \\
(\%)\end{array}$ & $\begin{array}{c}\text { Rheumatoid } \\
\text { arthritis (\%) }\end{array}$ & Healthy (\%) & p-value \\
\hline $\begin{array}{l}\text { Low level } \\
\text { positivity }\end{array}$ & 11.4 & 20.9 & 8.0 & 10.9 & 0.373 \\
\hline $\begin{array}{l}\text { Moderate level } \\
\text { positivity }\end{array}$ & 6.8 & 9.3 & 8.4 & 0 & 0.248 \\
\hline $\begin{array}{l}\text { High level } \\
\text { positivity }\end{array}$ & 2.3 & 2.3 & 56 & 0 & 0.00 \\
\hline
\end{tabular}

anti-CCP - anticyclic citrullinated peptid; anti-CCP 25-50 U/mL low; 50-75 U/mL moderate; above $75 \mathrm{U} / \mathrm{mL}$ high titre positivity.

Table 4. Published reports of the prevelance of anti-CCP antibodies in HBV-infected patients

\begin{tabular}{|l|c|c|c|c|}
\hline \multirow{2}{*}{ Studies } & \multicolumn{2}{|c|}{ HBV } & \multicolumn{2}{c|}{ RA } \\
\cline { 2 - 5 } & $\mathrm{n}$ & $\begin{array}{c}\text { anti-CCP positivity } \\
(\%, \mathrm{no})\end{array}$ & $\mathrm{n}$ & $\begin{array}{r}\text { anti-CCP positivity } \\
(\%, \text { no })\end{array}$ \\
\hline Sang-il Lee $2007 * 16$ & 176 & $0.6 \%,(1)$ & $* *$ & ** \\
\hline Lim MK 2009*17 & 240 & $4.5 \%,(11)$ & 10 & $13 \%(86.7)$ \\
\hline Zhou RF 2012*22 & 280 & $5.7 \%,(15)$ & 15 & $18 \%(72)$ \\
\hline Our study & 44 & $20.5 \%,(9)$ & 25 & \\
\hline
\end{tabular}

${ }^{*}$ reference no; ${ }^{* *}$ not studied.

HBV and HCV groups and healthy control group have not presented a statistically significant difference between their RF and anti-CCP positivity. However, RA group had higher RF and anti-CCP levels and displayed a striking difference to the rest of the groups $(\mathrm{p}<0.001$ for each). Group laboratory results are presented in Table 2. A comparison of anti-CCP positivity levels of groups (Table 3 ) presented that hepatitis $B$, hepatitis $C$ and healthy controls had lower levels of positivity (11.4\%, 20.9\%, 10.9\% respectively). However, RA group showed mostly high levels of anti-CCP positivity (56\%).

\section{Discussion}

In this study, we have analyzed anti-CCP positivity in asymptomatic chronic hepatitis $\mathrm{B}$ and $\mathrm{C}$ patients. We determined the anti-CCP positivity to be $20.5 \%$ and $32.5 \%$ in $\mathrm{HBV}$ and $\mathrm{HCV}$ patients respectively. However, most of these were low-level positivity.

Autoantibodies are widely used in rheumatoid disease diagnostics. Antinuclear antibody (ANA), RF and antiCCP are among the most commonly used autoantibodies in clinic practice. RF has been used in RA diagnostics since 1970s and is amongst 1987 ACR criteria and 2010 classification criteria. ${ }^{36}$

According to the literature, RF positivity changes between $17.5-42.7 \%$ in HBV patients and between 9.7-54\% in $\mathrm{HCV}$ patients. A correlation between RF, arthralgia and arthritis has been determined. ${ }^{16,17,19,20,22,24,25}$
Our study also resulted in $11.4 \% \mathrm{RF}$ levels in HBV patients and $16.3 \%$ for $\mathrm{HCV}$ patients, results not falling far from previous studies.

RF can also be induced in chronic infections (such as osteomyelitis, tuberculosis and subacute bacterial endocarditis) and acute infections besides chronic hepatitis. We had determined in a previous study that Brucellosis patients with arthritis had an RF level of $20 \%$. In addition to those, RF could also be positive in rheumatoid diseases such as Sjögren's Syndrome, systemic lupus erythematosus, cryoglobulinemia and in healthy individuals. ${ }^{37,38}$

Anti-CCP was first used in the 2000s as a RA diagnosis tool and took its place amongst classification criteria in 2010. Previous studies show anti-CCP levels of HBV patients as between 0-13.9\% (Table 4), and between $0-33 \%$ in HCV patients. Similarly, there has been a correlation detected between arthritis and anti-CCP positivity in these patients. Riccio et al. and Bassyouni et al. have determined $33 \%$ and $20 \%$, respectively, of anti-CCP positivity in HCV patients with musculoskeletal symptoms. ${ }^{19,29}$ In asymptomatic HCV patients, Liu Feng-Cheng et al. found $5.2 \%$ and Orge et al. $4.9 \%$ of anti-CCP positivity. ${ }^{14,19,20,24,25}$ We determined a $20.5 \%$ anti-CCP positivity in HBV and a $32.5 \%$ in HCV in our study. Our study showed higher Anti-CCP positivity than previous studies, but significant part of them in low titers (11.4\% in HBV, $20.9 \%$ in $\mathrm{HCV}$ in low titer).

Anti-CCP antibodies can be positive in other infections like tuberculosis (37\%) and Lyme disease (2\%) besides chronic hepatitis. As much as it is a sensitive and specific marker in RA diagnosis, it still can be found positive in systemic lupus erythematosus (8-17\%), Sjögren's Syndrome (3-7.5\%), scleroderma (5-10.6\%), ulcerative colitis (3\%), fibromyalgia (3\%) and polymyositis or dermatomyositis (14\%). 5,7-9,14,34

There are some limitations to our study. First of all, none of the patients had symptoms. An evaluation of symptomatic hepatitis patients could have provided more detailed information. Secondly, patients were not observed over a long period of time, so there was no data about long-term consequences in our findings.

In conclusion, we determined that RF and anti-CCP positivity is between $11.4 \%$ and $20.5 \%$ in HBV patients and between $16.3 \%$ and $32.5 \%$ in HCV patients. Therefore, chronic hepatitis should be considered a possibility particularly in patients with positive anti-CCP antibodies and low RF titer. 


\section{References}

1. Coenen D, Verschueren P, Westhovens R, Bossuyt X. Technical and diagnostic performance of 6 assays for the measurement of citrullinated protein/peptide antibodies in the diagnosis of rheumatoid arthritis. Clin Chem. 2007;53(3):498-504.

2. Kakumanu $P$, Yamagata $H$, Sobel ES, et al. Patients with pulmonary tuberculosis are frequently positive for anti-cyclic citrullinated peptide antibodies, but their sera also react with unmodified arginine-containing peptide. Arthritis Rheum. 2008;58(6):1576-1581.

3. Kakumanu P, Sobel ES, Narain $S$, et al. Citrulline dependence of anti-cyclic citrullinated peptide antibodies in systemic lupus erythematosus as a marker of deforming/erosive arthritis. J Rheumatol. 2009;36(12):2682-2690.

4. Gottenberg JE, Mignot S, Nicaise-Rolland P. Prevalence of anti-cyclic citrullinated peptide and anti-keratin antibodies in patients with primary Sjögren's syndrome. Ann Rheum Dis. 2005;64(1):114-147.

5. Ingegnoli F, Galbiati V, Zeni S, et al. Use of antibodies recognizing cyclic citrullinated peptide in the differential diagnosis of joint involvement in systemic sclerosis. Clin Rheumatol. 2007;26(4):510-514.

6. Takasaki Y, Yamanaka K, Takasaki C, et al. Anticyclic-citrullinated peptide antibodies in patients with mixed connective tissue disease. Mod Rheumatol. 2004;14(5):367-375.

7. Lima I, Santiago M. Antibodies against cyclic citrullinated peptides in infectious diseases: A systematic review. Clin Rheumatol. 2010;29:1345-1351.

8. Kappus MR, Sterling RK. Extrahepatic manifestations of acute hepatitis B virus infection. Gastroenterol Hepatol (NY). 2013;9(2):123126.

9. Buzgan T, Karahocagil MK, Irmak H, et al. Clinical manifestations and complications in 1028 cases of brucellosis: A retrospective evaluation and review of the literature. Int J Infect Dis. 2010;14(6):469-478.

10. Arnett FC, Edworthy SM, Bloch DA, et al. The American Rheumatism Association 1987 revised criteria for the classification of rheumatoid arthritis. Arthritis Rheum. 1998;31:315-324.

11. Aletaha D, Neogi T, Silman AJ, et al. 2010 rheumatoid arthritis classification criteria: An American College of Rheumatology/European League Against Rheumatism collaborative initiative. Ann Rheum Dis. 2010;69:1580-1588.
12. Lee $\mathrm{SI}$, Yoo $\mathrm{WH}$, Yun HJ, et al. Absence of antibody to cyclic citrullinated peptide in sera of nonarthritic patients with chronic hepatitis B virus infection. Clin Rheumatol. 2007;26(7):1079-1082.

13. Lim MK, Sheen DH, Lee YJ, Mun YR, Park M, Shim SC. Anti-cyclic citrullinated peptide antibodies distinguish hepatitis $B$ virus (HBV)-associated arthropathy from concomitant rheumatoid arthritis in patients with chronic HBV infection. J Rheumatol. 2009;36(4):712-716.

14. Bassyouni IH, Ezzat Y, Hamdy S, Talaat RM. Clinical significance of anti-cyclic citrullinated peptide antibodies in Egyptian patients with chronic hepatitis C virus genotype IV infection. Clin Chem Lab Med. 2009;47(7):842-847.

15. Riccio A, Postiglione L, La DP, Spano A, Marzocchella C, Tarantino G. Anti-cyclic citrullinated peptide antibodies in patients affected by HCV-related arthritis. J Biol Regul Homeost Agents. 2008;22(1):57-61.

16. Zhou RF, Liu XF, Chen Y, Wu F, Zeng AP, Cheng YJ. Detection of antibodies to cyclic citrullinated peptides and its clinical significance in patients with chronic hepatitis B virus infection. Zhonghua Yi XueZaZhi. 2012;12;92(22):1536-1539.

17. Örge E, Çefle A, Yazıcı A, Gürel Polat N, Hulagu S. The positivity of rheumatoid factor and anti-cyclic citrullinated peptide antibody in nonarthritic patients with chronic hepatitis C. Rheumatol Int. 2010;30:485-488.

18. Liu FC, Chao YC, Hou TY, et al. Usefulness of anti-CCP antibodies in patients with hepatitis $C$ virus infection with or without arthritis, rheumatoid factor, or cryoglobulinemia. Clin Rheumatol. 2008;27:463-467.

19. Conrad K, Roggenbuck D, Reinhold D, Dörner T. Profiling of rheumatoid arthritis associated autoantibodies. Autoimmun Rev. 2010;9(6):431-435.

20. Gokhan A, Turkeyler IH, Babacan $T$, et al. The antibodies cyclic citrullinated peptides (anti-CCP) positivity could be a promising marker in brucellosis patients presented with peripheric arthritis. Mod Rheumatol. 2014;24(1):182-187.

21. van Boekel MAM, Vossenaar ER, van den Hoogen FHJ, van Venrooij WJ. Autoantibody systems in rheumatoid arthritis: Specificity, sensitivity and diagnostic value. Arthritis Res. 2002;4:87-93. 